\title{
Effectiveness of Telemedicine on Patient Satisfaction: Meta Analysis
}

\author{
Sri Umiati'), Bhisma Murti'), Rita Benya Adriani²) \\ 1)Masters Program in Public Health, Universitas Sebelas Maret \\ ${ }^{2)}$ Health Polytechnics, Ministry of Health Surakarta
}

\section{ABSTRACT}

Background: Patient satisfaction is one indicator in the success of a treatment in the health sector. There are several ways to make this happen, including by simplifying the process of consultation, treatment and medication. Effectiveness in health services is very important. Telemedicine is a way offered to increase effectiveness in health services.

Subjects and Method: Meta analysis was performed with PICO as follows: The population in this study were patients. Health service intervention is in the form of telemedicine. Comparison in the form of Non Telemedicine/ visit services. Outcome in the form of patient satisfaction. The meta-analysis study was applied to this study with electronic data sources: Clinical Key, Google Scholar, MEDLINE/PubMed, Science Direct, Scopus. The article used is a full-text article with a randomized control trial (RCT) study design. There were 8 articles used in this study with a sample size of 2123 people who were divided into two groups (1113 people in the telemedicine group and 1010 people in the control/ non telemedicine group). Articles were analyzed using the
Review Manager 5.3 application. The results of this study aim to determine the Standardized Mean Difference (SMD) and the heterogeneity of the research sample.

Results: There is high heterogeneity between one experiment and another $\left(\mathrm{I}^{2}=81 \%\right.$; $\mathrm{P}$ $<0.0001)$ so that the Random Effect Model (REM) is used. The application of Telemedicine was able to increase patient satisfaction with Standardized Mean Different (SMD) of 0.41 compared to the control/ non-telemedicine group (SMD $0.41 ; 95 \% \mathrm{CI}=0.19$ to $-0.62 ; \mathrm{p}=$ 0.0002).

Conclusion: Providing telemedicine services was able to increase patient satisfaction with Standardized Mean Different (SMD) of 0.41 compared to non-telemedicine.

Keywords: Telemedicine, patient satisfaction

\section{Correspondence:}

Sri Umiati. Masters Program in Public Health, Universitas Sebelas Maret. Jl. Ir. Sutami No. 36 A, Surakarta 57126, Ccentral Java. Email: umi2374@gmail.com. Mobile: +6287834961974.

Cite this as:

Umiati S, Murti B, Adriani RB (2021). Effectiveness of Telemedicine on Patient Satisfaction: Meta Analysis. J Health Policy Manage. 06(01): 48-56. https://doi.org/10.26911/thejhpm.2021.06.01.05.

(c) (i) (-) Journal of Health Policy and Management is licensed under a Creative Commons Attribution-NonCommercial-ShareAlike 4.o International License.

\section{BACKGROUND}

The term telemedicine is not very specific. The World Health Organization defined telemedicine in 1997, as "the delivery of health care services, where distance is an important factor, by all health care professionals who use information communication technology for the exchange of valid information for the diagnosis, treatment and prevention of disease and injury, research and evaluation, and to continue the education of health care providers, all in the interest of advancing the health of individuals and their communities "(WHO, 1997).

With the increasing use of technology in healthcare, telehealth is highly emphasized as it can extend service providers to long-distance locations and take advantage of the availability of subject matter experts 
and overcome proximity barriers. Telehealth expands access, and has the potential to make healthcare more comfortable for patients, especially in rural areas, those with young children (child care) and those with reduced mobility (Muller et al, 2016).

Patient satisfaction is a growing concern in all aspects of health, and as a voice of the customer, it is a quality measure published in the USA through the Health Effectiveness Data and Information Set, and can be attributed to reimbursement from Medicare and Medicaid Centers through the Hospital Consumer Assessment Provider results and Health Care Systems, such as traditional modalities of health service delivery. Telehealth relies heavily on patient satisfaction reports because patients are the only source of information that can report how they were treated and whether the treatment received met patient care expectations (Kruse et al, 2017).

The widespread use of telemedicine in clinical practice and limited evidence to recommend the use of information and communication technology in headache management justifies randomized trials. In fact, telemedicine can help combat misdiagnosis, delay and treatment of suboptimal headaches, but we need to ensure that new technologies follow diagnostic quality and good clinical practice (Muller et al, 2016).

\section{SUBJECTS AND METHOD}

\section{A. Study Design}

This research is a systematic review and meta-analysis using literature from various electronic databases including: Clinical Key, Google Scholar, MEDLINE / PubMed, ProQuest, Science Direct, Scopus, and Spinger Link. The literature search was carried out using the following keywords: "telemedicine", "patient satisfaction", "ran- domized controlled trial", "telemedicine for patient satisfaction", "patien satisfaction randomized controlled trial", "telemedicine randomized controlled trial", "telehealth", "Telemedicine and visit", "nontelemedicine".

\section{B. Inclusion Criteria}

1) The article used is a full paper article

2) The article has an appropriate title and relates to the use of telemedicine on patient satisfaction.

3) Articles published in English and / or Indonesian

4) The article uses a Randomized Controlled Trial (RCT) study design

5) Include the results of the study in the form of the number of respondents, the mean value and the value of standard deviation (SD)

6) The research subjects were patients in health care

7) Intervention on research subjects in the form of telemedicine

8) The intervention in the control group was in the form of non telemedice

\section{Exclusion Criteria}

1) Not a full paper article

2) Articles that use quasi-experimental study design, protocol study, plot study, cohort, case control and cross-sectional study.

3) Articles use languages other than English and Indonesian

4) The research subjects were animals

D. Operational Definition of Variables Telemedicine is a medical practice using audio, visual and data communication, including treatment, diagnosis, consultation and treatment as well as medical data exchange and remote scientific discussions. Based on the above understanding, we can understand that the scope of telemedicine is quite broad, including the provision of long-distance health services (including clinical, educational and administrative 
services), through the transfer of information (audio, video, graphics), using telecommunication devices (audio- two-way interactive video, computer and telemetry) involving doctors, patients and others.

Non telemedicine/visit is a health service that allows patients to consult a doctor or other health worker by meeting in person

Satisfaction is the result of an assessment in the form of an emotional response (feelings of pleasure and satisfaction) to the patient due to the fulfillment of expectations or desires in using and receiving nurse services.

\section{E. Instruments}

Published articles obtained from various appropriate electronic journal databases include: Clinical Key, Google Scholar, MEDLINE/PubMed, Science Direct, Scopus. This research was conducted by searching and selecting the results of research on various races, ethnicities and locations in the world.

\section{F. Data Analysis}

This study was conducted using secondary data in the form of data from previous research results and data processing was carried out using the Review Manager (RevMan 5.3).

\section{RESULTS}

After the checking process was carried out, 913 of the same articles were found, so that the double articles were deleted. Therefore, there are a number of 876 articles that have been filtered. Of the 876 articles, 851 articles were excluded because they did not meet the inclusion criteria. Screening was done once again of the 51 existing articles, there were 43 articles that were not suitable because they did not meet the inclusion criteria.

There are 8 articles which are the final results of article selection that are included in the systematic review and meta-analysis process.

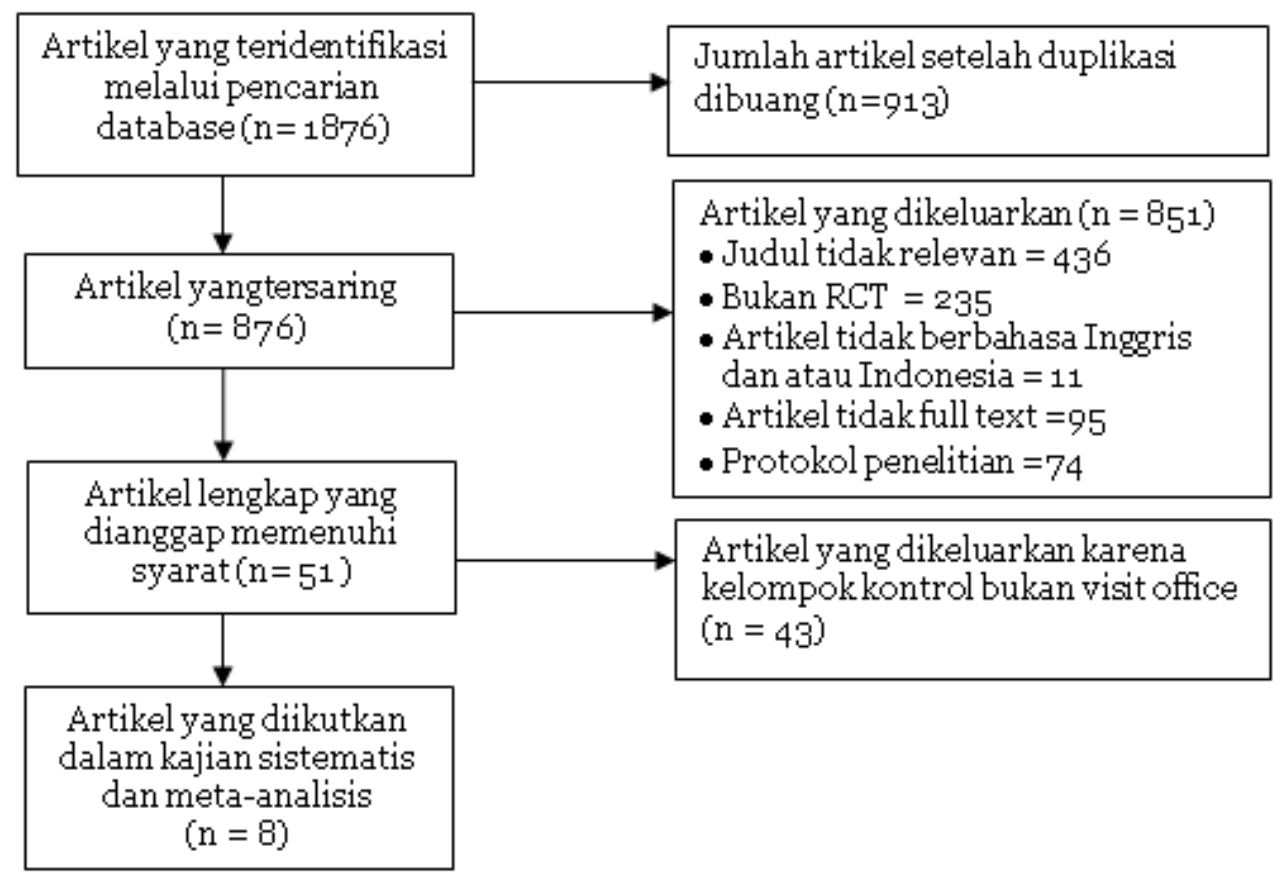

Figure 1. Flow Chart of Article Review Process 
Table 1. PICO (Population, Intervention, Comparison and Outcome) of each study

\begin{tabular}{|c|c|c|c|c|}
\hline Author & $\begin{array}{c}\mathbf{P} \\
\text { (Population) }\end{array}$ & I (Intervention) & C (Comparison) & O (Outcome) \\
\hline $\begin{array}{l}\text { Hwang et al } \\
\text { (2017) }\end{array}$ & $\begin{array}{l}\text { Patients with } \\
\text { heart failure }(n= \\
54)\end{array}$ & $\begin{array}{l}\text { Telemedicine with } \\
\text { video on software }\end{array}$ & $\begin{array}{l}\text { Traditional } \\
\text { outpatient / visit } \\
\text { office. }\end{array}$ & $\begin{array}{l}\text { Average value of the } \\
\text { patient satisfaction } \\
\text { questionnaire }\end{array}$ \\
\hline $\begin{array}{l}\text { Buvik et al } \\
(2018)\end{array}$ & $\begin{array}{l}\text { Orthopedic } \\
\text { patients }(\mathrm{n}= \\
389)\end{array}$ & $\begin{array}{l}\text { telemedicine } \\
\text { (remote } \\
\text { consultation) }\end{array}$ & $\begin{array}{l}\text { Clink standard } \\
\text { visit service }\end{array}$ & $\begin{array}{l}\text { Patient-complete } \\
\text { questionnaire or a } \\
\text { three-level Euro- } \\
\text { pean five-dimensi- } \\
\text { onal quality of life } \\
\text { index (EQ-5D-3L) }\end{array}$ \\
\hline $\begin{array}{l}\text { Ruiz et al } \\
\text { (2019) }\end{array}$ & $\begin{array}{l}\text { Patients with } \\
\text { Type } 1 \text { DM (n = } \\
\text { 379) }\end{array}$ & $\begin{array}{l}\text { PLATEDIAN } \\
\text { (Telemedicine on } \\
\text { Metabolic Control } \\
\text { in Type 1 DM } \\
\text { Andalusian } \\
\text { Patients) }\end{array}$ & $\begin{array}{l}\text { Direct daily } \\
\text { injection service }\end{array}$ & $\begin{array}{l}\text { Average value of the } \\
\text { patient satisfaction } \\
\text { questionnaire }\end{array}$ \\
\hline $\begin{array}{l}\text { Vonstorc et } \\
\text { al (2019) }\end{array}$ & $\begin{array}{l}\text { Patients with } \\
\text { Type } 2 \text { DM }(\mathrm{n}= \\
\text { 115) }\end{array}$ & mputer, & $\begin{array}{l}\text { Standard clinic } \\
\text { care }\end{array}$ & $\begin{array}{l}\text { Average value of the } \\
\text { patient satisfaction } \\
\text { questionnaire }\end{array}$ \\
\hline $\begin{array}{l}\text { Richter et al } \\
(2015)\end{array}$ & $\begin{array}{l}\text { Counseling } \\
\text { patients stop } \\
\text { smoking }(\mathrm{n}= \\
566)\end{array}$ & $\begin{array}{l}\text { Skype-like video } \\
\text { counseling }\end{array}$ & $\begin{array}{l}\text { Face-to-face } \\
\text { trained counselors }\end{array}$ & $\begin{array}{l}\text { Value of the patient } \\
\text { satisfaction } \\
\text { questionnaire }\end{array}$ \\
\hline $\begin{array}{l}\text { Kravitz et al } \\
(2018)\end{array}$ & $\begin{array}{l}\text { Patients with } \\
\text { muscoskeletal } \\
\text { pain }(\mathrm{n}=215)\end{array}$ & $\begin{array}{l}\text { MHealth support } \\
\text { n-of-1 intervention }\end{array}$ & Regular service & $\begin{array}{l}\text { Standard patient } \\
\text { satisfaction } \\
\text { questionnaire }\end{array}$ \\
\hline $\begin{array}{l}\text { Sood et al } \\
(2017)\end{array}$ & $\begin{array}{l}\text { DM patients ( } \mathrm{n} \\
=282)\end{array}$ & $\begin{array}{l}\text { Telemedicine } \\
\text { consultation }\end{array}$ & Standard service & $\begin{array}{l}\text { Patient satisfaction } \\
\text { service scoring }\end{array}$ \\
\hline $\begin{array}{l}\text { Moffet et al } \\
\text { (2017) }\end{array}$ & $\begin{array}{l}\text { Patients after } \\
\text { Total Knee } \\
\text { Arthroplasty ( } \mathrm{n} \\
=180 \text { ) }\end{array}$ & $\begin{array}{l}\text { Home Telereha- } \\
\text { bilitation After } \\
\text { Total Knee } \\
\text { Arthroplasty }\end{array}$ & Regular service & $\begin{array}{l}\text { Patient satisfaction } \\
\text { using the Satisfac- } \\
\text { tion Questionnaire } \\
\text { (HCSQ) at E4 }\end{array}$ \\
\hline
\end{tabular}

There were 8 randomized controlled trial (RCT) studies as a source of systematic review and meta-analysis of the effectiveness of telemedicine on patient satisfaction in this study. An overview of the PICO (Population, Intervention, Comparison, Outcome) of 8 articles used in the systematic study and meta-analysis in this study can be seen in table 1 .

Interpretation of the results of the meta-analysis of the 8 primary research articles in this study can be seen in the forest plot image (Figure 2). Based on the results of the analysis using RevMan 5.3 software, it is known that there is high heterogeneity between one experiment and another $\left(\mathrm{I}^{2}=81 \% ; \mathrm{P}<0.0001\right)$ so that the Random Effect Model (REM) is used. The provision of telemedicine services was able to increase the score of patient satisfaction with Standardized Mean Different (SMD) by 0.41 compared to without telemedicine $(\mathrm{SMD}=0.41 ; 95 \% \mathrm{CI}=0.19$ to $0.62 ; \mathrm{p}=$ 0.0002). 
Umiati et al./ Effectiveness of Telemedicine on Patient Satisfaction

Table 2. Research Quality Assessment (Critical Appraisal)

\begin{tabular}{|c|c|c|c|c|c|c|c|c|}
\hline \multirow[b]{2}{*}{ Items } & \multicolumn{8}{|c|}{ Author (year) } \\
\hline & $\begin{array}{c}\text { Hwang } \\
\text { et al } \\
(2017)\end{array}$ & $\begin{array}{c}\text { Buvik } \\
\text { et al } \\
(2018)\end{array}$ & $\begin{array}{c}\text { Ruiz et } \\
\text { al } \\
(\mathbf{2 0 1 9})\end{array}$ & $\begin{array}{c}\text { Vonstorc } \\
\text { et al } \\
(2019)\end{array}$ & $\begin{array}{l}\text { Richter } \\
\text { et al, } \\
\text { (2015) }\end{array}$ & $\begin{array}{c}\text { Kravitz } \\
\text { et al } \\
(\mathbf{2 0 1 8})\end{array}$ & $\begin{array}{c}\text { Sood et } \\
\text { al } \\
(2017) \\
\end{array}$ & $\begin{array}{c}\text { Moffet } \\
\text { et al } \\
(2017)\end{array}$ \\
\hline $\begin{array}{l}\text { Relevance of } \\
\text { goals and } \\
\text { problems }\end{array}$ & 1 & 1 & 1 & 1 & 1 & 1 & 1 & 1 \\
\hline $\begin{array}{l}\text { Relevance of } \\
\text { methods and } \\
\text { problems }\end{array}$ & 1 & 1 & 1 & 1 & 1 & 1 & 1 & 1 \\
\hline $\begin{array}{l}\text { Sample } \\
\text { adequacy }\end{array}$ & 1 & 1 & 1 & 1 & 1 & 1 & 1 & 1 \\
\hline $\begin{array}{l}\text { Sample } \\
\text { validation }\end{array}$ & 1 & 1 & 1 & 1 & 1 & 1 & 1 & 1 \\
\hline $\begin{array}{l}\text { Comparable } \\
\text { Cases and } \\
\text { Controls }\end{array}$ & 1 & 1 & 1 & 1 & 1 & 1 & 1 & 1 \\
\hline $\begin{array}{l}\text { There is no } \\
\text { bias }\end{array}$ & 1 & $\mathrm{O}$ & 1 & 1 & 1 & 1 & 1 & $\mathrm{O}$ \\
\hline $\begin{array}{l}\text { Information } \\
\text { data tracking }\end{array}$ & 1 & 1 & 1 & 1 & 1 & 1 & 1 & 1 \\
\hline $\begin{array}{l}\text { Analysis of } \\
\text { relevant and } \\
\text { valid data }\end{array}$ & 1 & 1 & 1 & 1 & 1 & 1 & 1 & 1 \\
\hline $\begin{array}{l}\text { Relevance } \\
\text { Effect Size }\end{array}$ & 1 & 1 & 1 & 1 & 1 & 1 & 1 & 1 \\
\hline $\begin{array}{l}95 \% \mathrm{CI} \\
\text { reporting }\end{array}$ & 1 & 1 & 1 & 1 & 1 & 1 & 1 & 1 \\
\hline $\begin{array}{l}\text { Reported } \\
\text { confounding } \\
\text { factor }\end{array}$ & 1 & 1 & 1 & $\mathrm{O}$ & 1 & 1 & 1 & 1 \\
\hline $\begin{array}{l}\text { Results can be } \\
\text { applied }\end{array}$ & 1 & 1 & 1 & 1 & 1 & 1 & 1 & 1 \\
\hline Total & 12 & 11 & 12 & 11 & 12 & 12 & 12 & 11 \\
\hline
\end{tabular}

Note:

Yes $=1$

No $=0$

\section{a. Forest plot}

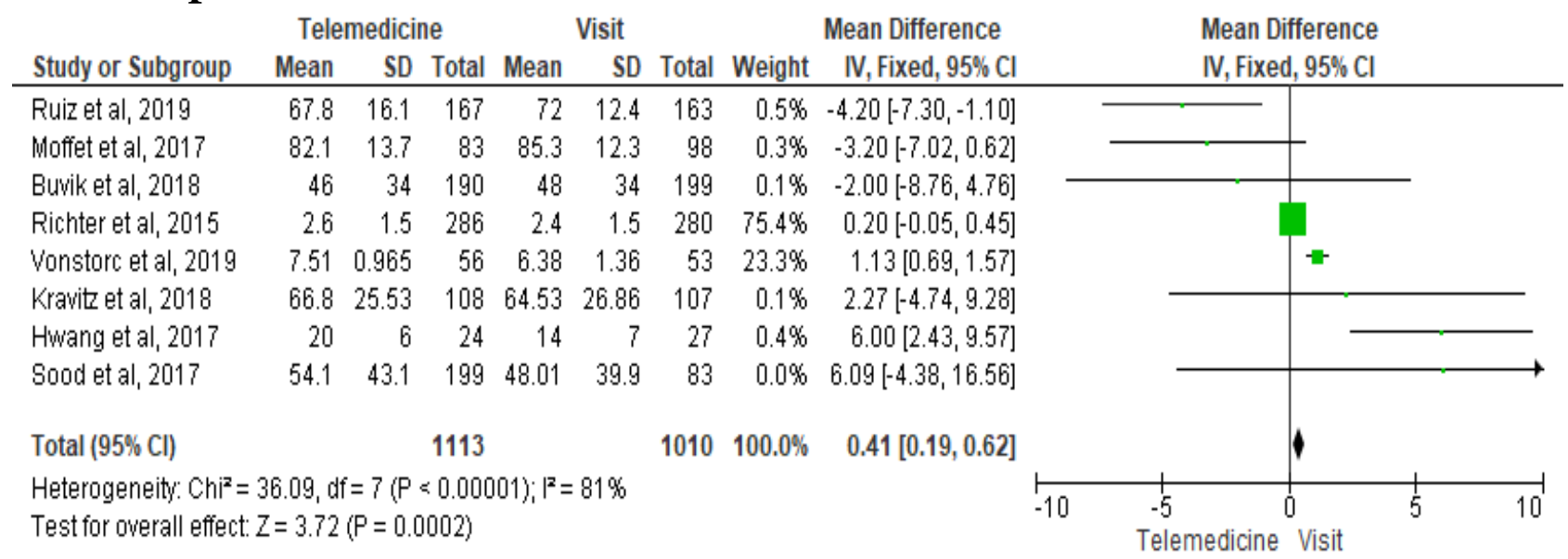

Figure 2. Forest Plot 
A funnel plot is a plot that depicts the effect size of each study on the estimate of its accuracy which is usually the standard error. The interpretation of the funnel plot results shows that there is no publication bias, indicated by: 1 . The plot is symmetrical on the right and left sides, 2. The distance between the plots is balanced, 3 . The SE value $<0.5$.
The funnel plot image in this study shows that there is no publication bias. This is indicated by the symmetry of the right and left sides of the plot. On the right side there are 4 circles and on the left there are 4 circles. The standard error on the right is between 0 and 2 and the standard error on the left lies between 0 and 6 .

\section{b. Forest plot}

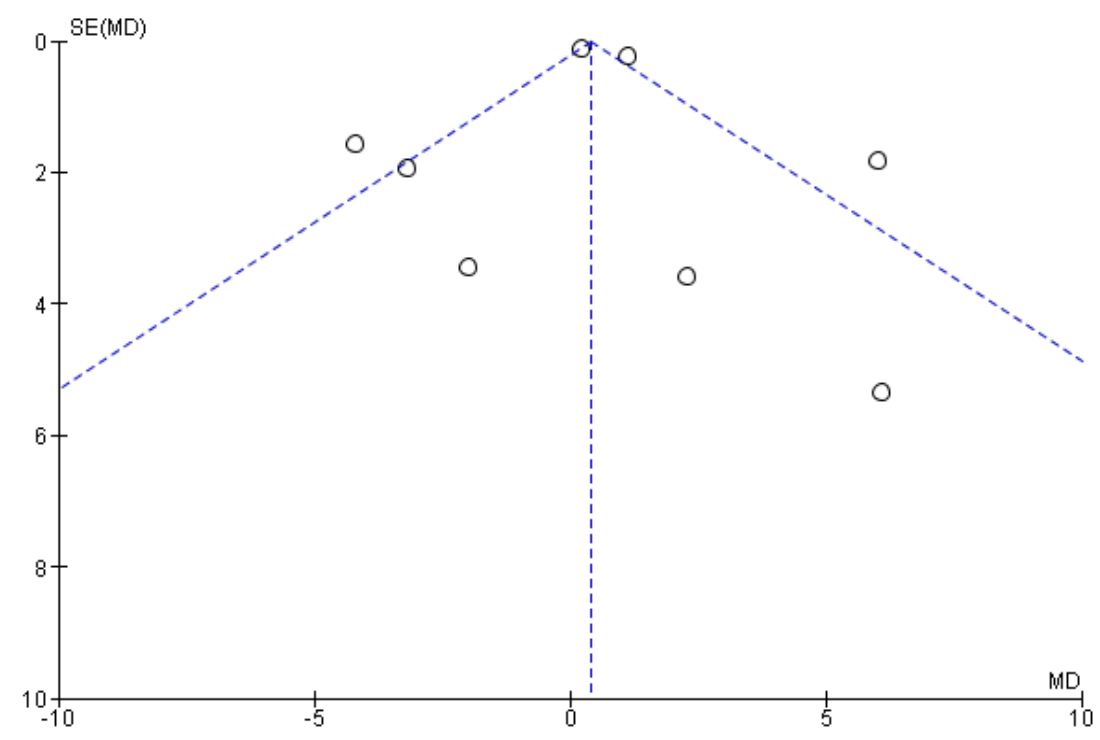

Figure 3. Funnel Plot

\section{DISCUSSION}

Telemedicine can be more simply defined as the application of information and communication technology to provide health care services remotely without the need for direct contact with patients (Siegel, 2017). This study shows that telemedicine can be more effective than direct visits to health facilities

Telemedicine is already widely used in medicine. When telemedicine was evaluated in 2012, nearly half of US hospitals were found to have an active program. The impetus for this expansion is partly to keep up with the times, but telemedicine is also uniquely positioned to address rising healthcare costs, a focus on patient-centered care. Telemedicine to provide health care as a service, and address growing problems with access to service providers in a timely manner (Siegel, 2017).

Telemedicine can also be called telehealth can provide high quality services, increase access to care, increase self-awareness and items empower patients to manage their chronic conditions. Health care should embrace telehealth because reducing missed appointments, is a good modality for education, reduces waiting times, reduces readmissions and improves treatment adherence. Most importantly, however, policymakers need to help laws catch up with technology by enabling additional means of reimbursement for telehealth as these modalities increase out- 
comes, which improve public health (Kruse et al, 2017).

Telemedicine has been shown to provide effective treatments for a variety of behaviors and health outcomes. Telemedicine versus direct patient care found telemedicine and direct care to be equally effective, and both achieved high levels of satisfaction among both patient and provider (Ritcher, 2015).

Some of the researchers mentioned above that telemedicine was more effective than direct visits to health facilities, while others said that telemedicine was as effective as direct visits. There is also research that states that direct visits are better and more effective in increasing patient satisfaction. This is related to various demographic conditions, culture, and lifestyle factors.

In some areas, it is not possible to use technological equipment for various reasons, for example electricity and grids will experience difficulties. On the other hand, in areas that have experienced development, it is possible to develop telemedicine.

The results of data processing using technology applications will save time and effort.

\section{AUTHOR CONTRIBUTION}

Sri Umiati as the main researcher is as a research implementer, collecting research data, formulating research articles, and processing data. Bhisma Murti played a role in the formulation of a framework for thinking and the process of analyzing research data. Rita Benya Adriani was involved in the background writing and discussion of the research.

\section{CONFLICT OF INTEREST}

There is no conflict of interest in this study.
FUNDING AND SPONSORSHIP

The source of funds in this study is from the Ministry of Health of the Republic of Indonesia

\section{ACKNOWLEDGEMENT}

The researcher expresses his gratitude to the Ministry of Health of the Republic of Indonesia, Sebelas Maret University Library. Electronic databases: Clinical Key, Google Scholar, MEDLINE/PubMed, Science Direct, Scopus

\section{REFERENCE}

Peris MA, Hoyo JD, Bebia P, Faubel R, Barrios A, Bastida G, Valdivieso $\mathrm{B}$, Nos $\mathrm{P}$ (2015). Telemedicine in inflammatory bowel disease: Opportunities and approaches. Inflamm Bowel Dis. 21 (2): 392-399. https://doi.org/10.1097/mib.0000000000000241.

Brouwers RWM, Kraal JJ, Traa SCJ, Spee RF, Oostveen LMLC, Kemps HMC (2017). Effects of cardiac telerehabilitation in patients with coronary artery disease using a personalised patientcentred web application: protocol for the SmartCare- CAD randomised controlled trial. BMC Cardiovascular Disorders. 17, 46 (2017). https://doi.org/10.1186/s12872-017-0477-6.

Buvik A, Bugge E, Knutsen G, Småbrekke A, Wilsgaard T (2019). Patient reported outcomes with remote orthopaedic consultations by telemedicine: A randomised controlled trial. J Telemed Telecare. 25(8):451-459. https://doi.org/10.1177/1357633x18783921.

Buvik A, Bergmo TS, Bugge E, Smaabrekke A, Wilsgaard T, Olsen JA (2019). Cost-effectiveness of telemedicine in remote orthopedic consultations: Randomized Controlled Trial. J Med Internet Res. 21(2): e11330. https://doi.org/10.2196/11330. 
Culmer N, Smith T, Stager C, Meyer H, Quick S, Grimm K (2019). Evaluation of the triple aim of medicine in prehospital telemedicine: A systematic literature review. J Telemed Telecare. 26(10): 571-580. https://doi.org/10.1177/1357633X19853461.

Coelho KR (2011). Identifying telemedicine services to improve access to specialty care for the underserved in the San Francisco Safety Net. Int J Telemed Appl. 2011: 523161. https://doi.org/10.1155/2011/523161.

Dobke MK, Bhavsar D, Herrera F (2011). Do telemedicine wound care specialist consults meet the needs of the referring physician? A survey of primary care providers. Int $\mathrm{J}$ Telemed Appl. 2011:321376. https://doi.org/10.1155/2011/321376.

Fletcher KT, Dicken FW, Adkins MM, Cline TA, Mcnulty BN, Shinn JB, Bush ML (2019). Audiology telemedicine evaluations: Potential Expanded Applications. Otolaryngol Head Neck Surg. 161(1): 63-66. https://doi.org/10.1177/0194599819835541

Hwang R, Bruning J, Morris NR, Mandrusiak A, Russell T (2017). Home-based telerehabilitation is not inferior to a centre-based program in patients with chronic heart failure: A randomised trial. J Physiother. 63(2): 101-107 https://doi.org/10.1016/j.jphys.2017.02.017.

Jamil M, Khairan A, Fuad A (2015). Implementasi aplikasi telemedicine berbasis jejaring sosial dengan pemanfaatan teknologi cloud computing. Jurnal Edukasi \& Penelitian Informatika. 1(1). http://dx.doi.org/10.26418/jp.v1i1.9930.

Jeminiwa R, Hohmann L, Qian J, Garza K, Hansen R, Fox BI (2019). Impact of eHealth on medication adherence among patients with asthma: A systematic review and meta-analysis. Respir Med. 149: 59-68. https://doi.org/10.1016/j.rmed.2019.02.011.

de Jong MJ, Jong AEM, Romberg-Camps MJ, Becx MC, Maljaars JP, Cilissen M, Bodegraven AA, et al. (2017). Telemedicine for management of inflammatory bowel disease (myIBDcoach): a pragmatic, multicentre, randomised controlled trial. Lancet. 390(10098): 959-968. https://doi.org/10.1016/S0140-6736(17)31327-2.

Kelton DK, Szulewski A, Howes D (2017). Real-time video telemedicine applications in the emergency department: a scoping review of literature. CJEM. 20(6): 920-928. https://doi.org/10.1017/cem.2017.382.

Kravitz RL, Schmid CH, Marois M, Wilsey B, Ward D, Hays RD, Duan N, et al. (2018). Effect of mobile device-supported single-patient multi-crossover trials on treatment of chronic musculoskeletal pain: A Randomized clinical trial. JAMA Intern Med. 178(10): 1368-1377. https://doi.org/10.1001/jamainternmed.2018.3981.

Kruse CS, Krowski N, Rodriguez B, Tran L, Vela J (2017). Telehealth and patient satisfaction: A systematic review and narrative analysis. BMJ Open. 1-12. https://doi.org/10.1136/bmjopen-2017-016242.

Melian C, Kieser D, Frampton C, Wyatt MC (2020). Teleconsultation in orthopaedic surgery: A systematic review and meta-analysis of patient and physician experiences. J Telemed Telecare. https://doi.org/10.1177/1357633X20950995 .

Ming W, Mackillop LH, Farmer AJ, Loerup L, Bartlett K, Levy JC, Tarassenko L, et al. (2016). Telemedicine technologies for diabetes in pregnancy: A sys- 
tematic review and meta-analysis. $\mathrm{J}$ Med Internet Res. 18(11): e290 https://doi.org/10.2196/jmir.6556.

Muller KI (2017). Headache patients' satisfaction with telemedicine: A 12-month follow-up randomized non-inferiority trial 1-9. Eur J Neurol. 24(6): 807815. https://doi.org/10.1111/ene.13294.

Murti B (2018). Prinsip dan Metode Riset Epidemiologi (Edisi V). Surakarta: Bintang Fajar Offset

Smith-Strøm H, Igland J, Østbye T, Tell GS, Hausken MF, Graue M, Skeie S, et al. (2018). The effect of telemedicine follow-up care on diabetes- related foot ulcers: A cluster randomized controlled noninferiority trial. Diabetes Care. 41(1): 96-103 https://doi.org/10.2337/dc17-1025.

Piga M, Cangemi I, Cauli A (2017). Telemedicine for patients with rheumatic diseases: Systematic review and proposal for research agenda. Semin Arthritis Rheum. 47(1): 121-128. https://doi.org/10.1016/j.semarthrit.2017.03.014

Robb JF, Hyland MH, Goodman AD (2019). Comparison of telemedicine versus in-person visits for persons with multiple sclerosis: A randomized crossover study of feasibility, cost, and satisfaction. Multiple Journal. 36: 101-258. https://doi.org/10.1016/j.msard.2019.05.001.

Sood A, Watts SA, Johnson JK, Hirth S, Aron DC (2017). Telemedicine consultation for patients with diabetes mellitus: a cluster randomised controlled trial. J Telemed Telecare. 24(6): 385391. https://doi.org/10.1177/1357633X17704346.

Spencer T, Noyes E, Biederman J (2020). Telemedicine in the management of ADHD: Literature review of telemedicine in ADHD. J Atten Disord. 24(1): 3-9. https://doi.org/10.1177/1087054719859081.

Tchero H, Noubou L, Becsangele B, Mukisimukaza M, Retali G, Rusch E (2017). Telemedicine in diabetic foot care: A systematic literature review of interventions and meta-analysis of controlled trials. Int $\mathrm{J}$ Low Extrem Wounds. https://doi.org/10.1177/1534734617739195 .

Tousignant M, Moffet H, Nadeau S, Mérette C, Boissy P, Corriveau H, Marquis F, et al. (2015). Cost analysis of in-home telerehabilitation for post-knee arthroplasty. J Med Internet Res. 17(3): e83. 23(2): 1-8. https://doi.org/10.1089/tmj.2016.0060. 